\title{
Chemokines and Glycoprotein120 Produce Pain Hypersensitivity by Directly Exciting Primary Nociceptive Neurons
}

\author{
Seog Bae Oh, ${ }^{1}$ Phuong B. Tran, ${ }^{1}$ Samantha E. Gillard, ${ }^{1}$ Robert W. Hurley, ${ }^{2}$ Donna L. Hammond, ${ }^{2}$ and \\ Richard J. Miller ${ }^{1}$ \\ ${ }^{1}$ Department of Neurobiology, Pharmacology, and Physiology, and 2Department of Anesthesia and Critical Care and The \\ Committee on Neurobiology, University of Chicago, Chicago, Illinois 60637
}

Human immunodeficiency virus-1 (HIV-1) infection is associated with numerous effects on the nervous system, including pain and peripheral neuropathies. We now demonstrate that cultured rat dorsal root ganglion (DRG) neurons express a wide variety of chemokine receptors, including those that are thought to act as receptors for the HIV-1 coat protein glycoprotein120 (gp120). Chemokines that activate all of the known chemokine receptors increased $\left[\mathrm{Ca}^{2+}\right]_{i}$ in subsets of cultured DRG cells. Many neurons responded to multiple chemokines and also to bradykinin, ATP, and capsaicin. Immunohistochemical studies demonstrated the expression of the CXCR4 and CCR4 chemokine receptors on populations of DRG neurons that also expressed substance P and the VR1 vanilloid receptor.
RT-PCR analysis confirmed the expression of CXCR4, CX3CR1, CCR4, and CCR5 mRNAs in DRG neurons. Chemokines and gp120 produced excitatory effects on DRG neurons and also stimulated the release of substance P. Chemokines and gp120 also produced allodynia after injection into the rat paw. Thus these results provide evidence that chemokines and gp120 may produce painful effects via direct actions on chemokine receptors expressed by nociceptive neurons. Chemokine receptor antagonists may be important therapeutic interventions in the pain that is associated with HIV-1 infection and inflammation.

Key words: neuropathies; AIDS; pain; dorsal root ganglia; G-protein-coupled receptor; substance $P$
Inflammation is associated commonly with states of heightened pain sensitivity. Although the mechanisms underlying this phenomenon are not understood completely, it is believed that factors secreted from leukocytes in inflammatory infiltrates play an important role in the generation of hyperalgesia and allodynia (Millan, 1999). Chemokines are small chemotactic cytokines that act as important messenger molecules between cells of the immune system. Chemokines produce their effects by activating a family of G-protein-coupled receptors (GPCRs; Asensio and Campbell, 1999). Some chemokine receptors also act as cellular binding sites for the human immunodeficiency virus-1 (HIV-1) coat protein glycoprotein120 (gp120), allowing the virus to interact with, and infect, target cells (Horuk, 1999). Patients infected with the HIV-1 virus display a variety of neurological symptoms. These include increased sensitivity to pain and different types of sensory and motor neuropathies (Brannagan et al., 1997; Hewitt et al., 1997; Griffin et al., 1998; Bouhassira et al., 1999). Indeed, it has been demonstrated that gp120 is capable of producing pain when administered peripherally (Eron et al., 1996) or centrally (Milligan et al., 2000). One way in which gp120 might produce such effects is indirectly via an action on glial or microglial cells,

\footnotetext{
Received Feb. 20, 2001; revised April 20, 2001; accepted April 30, 2001.

This work was supported by National Institutes of Health Grants DA02121, DA13141, MH40165, NS33826, DK44840, and NS21442 to R.J.M.; DA06736 to D.L.H.; and DA05784 to R.W.H. S.B.O. was supported in part by postdoctoral fellowships program from Korea Science and Engineering Foundation. We thank Dr. Pat Gray of ICOS Corporation for the generous supply of many of the chemokines used in these studies and Dr. Robert Elde (University of Minnesota, Minneapolis, MN) for antibodies to the VR1 receptor.

Correspondence should be addressed to Dr. Richard J. Miller, Department of Molecular Pharmacology and Biological Chemistry, Northwestern University Medical School, 303 East Chicago Avenue, Searle 7-577, Chicago, IL 60611. E-mail: r-miller10@northwestern.edu.

Copyright (C) 2001 Society for Neuroscience 0270-6474/01/215027-09\$15.00/0
}

causing them to release inflammatory cytokines (Milligan et al., 2000). Alternatively, gp120 or chemokines may act directly on sensory neurons to elicit pain. In this regard, it has been shown recently that various types of neurons express chemokine receptors (Miller and Meucci, 1999). Consistent with this finding, we now demonstrate that many small nociceptive neurons express receptors for a highly diverse group of chemokines. Activation of these receptors by chemokines or by gp120s excites these neurons and produces allodynia. Thus neuronal chemokine receptors may mediate directly the enhanced sensitivity to pain in inflammatory states or in association with HIV-1 infection.

\section{MATERIALS AND METHODS}

Materials. The chemokines used in these experiments were purchased from R \& D Systems (Minneapolis, MN) or supplied by Dr. Pat Gray of ICOS Corporation (Bothell, WA). The chemokines and their concentration used in the in vitro experiments were as follows: B-cell-activating chemokine-1 (BCA-1; $50 \mathrm{~nm})$, eotaxin (50 nM), fractalkine (100 nM), I-309 (50 nM), interleukin-8 (IL-8; $50 \mathrm{nM}), \gamma$-interferon-inducible protein-10 (IP-10; $50 \mathrm{~nm}$ ), liver- and activation-related chemokine (LARC; $50 \mathrm{nM}$ ), monocyte chemoattractant protein-1 (MCP-1; $50 \mathrm{nM}$ ), macrophage inflammatory protein- $1 \beta$ (MIP- $1 \beta ; 50 \mathrm{nM}$ ), macrophagederived chemokines (MDC; $50 \mathrm{~nm}$ ), regulated on activation normal T-cell expressed and secreted (RANTES; $50 \mathrm{nM}$ ), stromal cell-derived factor- $1 \alpha$ (SDF- $1 \alpha ; 50 \mathrm{nM}$ ), secondary lymphoid tissue chemokine (SLC; $50 \mathrm{nM}$ ), thymus- and activation-related chemokine (TARC; $50 \mathrm{nM}$ ), and viral macrophage inflammatory protein-I, II, III (vMIP-I, II, III; 100 $\mathrm{nM})$. Lyophilized proteins were reconstituted in $0.1 \% \mathrm{BSA} / \mathrm{PBS}$, and aliquots were stored at $-20^{\circ} \mathrm{C}$. Recombinant gp120 HIV-1 ${ }_{\text {III B }}$ and gp120 SIV $_{\text {mac251 }}$ were purchased from Intracel Corporation (Issaquah, WA), reconstituted in $0.1 \%$ BSA/PBS solution $(100$ and $300 \mu \mathrm{g} / \mathrm{ml}$, respectively), and stored at $-70^{\circ} \mathrm{C}$. The preparations of recombinant gp120 were purified by immunoaffinity chromatography to $95 \%$ purity. On the day of experiment a working solution $(100 \times)$ was prepared just before experimentation. The final concentration of gp120 HIV-1 $1_{\text {IIIB }}$ and gp120 $\mathrm{SIV}_{\text {mac251 }}$ applied in the experiment was $200 \mathrm{pM}$. Chemokines and gp120 
were diluted to their final concentration with the same extracellular solution. Bradykinin, ATP, and capsaicin were purchased from Sigma (St. Louis, MO); $1 \mu \mathrm{M}$ bradykinin, $1 \mu \mathrm{M}$ capsaicin, and $100 \mu \mathrm{M}$ ATP were used in the experiments.

Preparation of dorsal root ganglion (DRG) neurons. Cultures of DRG neurons from neonatal rats were prepared with a modification of the methods described previously (Thayer et al., 1988). Briefly, 2- to 5-d-old Holtzman rats were decapitated, and the DRGs were dissected under aseptic conditions, after which they were treated sequentially with collagenase (Sigma), collagenase/dispase (Boehringer Mannheim, Mannheim, Germany), and trypsin (Life Technologies, Gaithersburg, MD) in HBSS (Life Technologies) for $10 \mathrm{~min}$ at $37^{\circ} \mathrm{C}$. The digestion was halted by the addition of an equal volume of horse serum $\left(4^{\circ} \mathrm{C}\right)$ and subsequent centrifugation (5 min, $1000 \mathrm{rpm}$ ). The ganglia were resuspended in Ham's medium mixture F12 (Life Technologies) supplemented with 10\% fetal bovine serum (FBS; Atlanta Biologicals, Norcross, GA), $\mathrm{N}_{2}$ supplement (Life Technologies), $50 \mathrm{ng} / \mathrm{ml}$ nerve growth factor (NGF; Collaborative Biomedical Products, Bedford, Ma), and penicillin and streptomycin $(100 \mu \mathrm{g} / \mathrm{ml}$ and $100 \mathrm{U} / \mathrm{ml}$, respectively); the ganglia were dissociated into single cells by trituration via a series of heat-polished Pasteur pipettes. Several modifications were made to the protocol to minimize contamination of the cultures by non-neuronal cells. In most experiments the cell suspensions were preplated on uncoated tissue culture dishes for $2 \mathrm{hr}$ at $37^{\circ} \mathrm{C}$. Nonadherent neuronal cells were dislodged from the dishes by gentle pipetting. Then the cells were plated on polyornithine-coated (Sigma) and laminin-coated (Collaborative Biomedical Products) coverslips (25 mm diameter) and incubated in Ham's medium mixture F12 with the additives listed above, except that FBS was reduced to $0.5 \%$. The medium was replaced every $2-3 \mathrm{~d}$. Finally, $1-10 \mu \mathrm{M}$ cytosine arabinoside (Sigma) was added to inhibit the proliferation of non-neuronal cells, including ganglionic fibroblasts. Cultures were maintained at $37^{\circ} \mathrm{C}$ in a water-saturated atmosphere with $5 \% \mathrm{CO}_{2}$ for up to 2 weeks. Neonatal DRG neurons prepared in this manner were used for Ca-imaging, patch-clamp, immunohistochemistry, and RT-PCR experiments.

DRG neurons from adult rats also were prepared to examine the differential expression of chemokine receptors in mature DRG neurons. The DRG neurons were acutely isolated by essentially the same enzymatic treatments and mechanical trituration as described above. Because adult DRG neurons were used only on the day of preparation, the ganglia were triturated mechanically in plating media (DMEM with $10 \%$ FBS, $1 \%$ streptomycin, and 10,000 U penicillin, $\mathrm{pH} 7.4$; osmolarity 305$)$, using a series of heat-polished Pasteur pipettes. The dissociated neurons were allowed to settle for at least $1 \mathrm{hr}$ in plating media. Neurons prepared in this manner were used in the $\mathrm{Ca}$-imaging experiments.

Intracellular $\mathrm{Ca}^{2+}$ imaging. The AM form of fura-2 (fura-2 AM; Molecular Probes, Eugene, OR) was used as the fluorescent $\mathrm{Ca}$ indicator. All measurements were made at room temperature as described previously (Meucci et al., 1998). The DRG cells grown on the coverslips were loaded with fura-2 AM $(5 \mu \mathrm{M})$ for $20 \mathrm{~min}$ at room temperature in a balanced salt solution [BSS; containing (in mM) $145 \mathrm{NaCl}, 5 \mathrm{KCl}, 2$ $\mathrm{CaCl}_{2}, 1 \mathrm{MgCl}_{2}, 10 \mathrm{HEPES}$, and 10 glucose]. Then the cells were rinsed with BSS and incubated in BSS for an additional $30 \mathrm{~min}$ to de-esterify the dye. The coverslips were mounted onto the chamber $(500 \mu$ l total volume), which then was placed onto the inverted microscope, and perfused continuously by BSS at a rate of $2 \mathrm{ml} / \mathrm{min}$. Intracellular free calcium concentration was measured by digital video microfluorometry with an intensified CCD camera coupled to a microscope and software (Metafluor) on a Pentium computer. Cells were illuminated with a $150 \mathrm{~W}$ xenon arc lamp, and excitation wavelengths $(340 / 380 \mathrm{~nm})$ were selected by a filter changer. We applied the chemokines and gp120s for 3 min by adding $1 \mathrm{ml}$ of solution at its final concentration directly to the bath chamber after stopping the flow. The number of cells responding to chemokines or gp120s was counted $(>10 \%)$.

Electrophysiology. To ensure a good clamp of cultured neonatal DRG neurons, we removed the neuronal processes by replating the cells $1 \mathrm{hr}$ before the experiment. Current-clamp recordings were made to evoke action potentials and to measure the changes of membrane potential by using the tight seal whole-cell configuration of the patch-clamp technique (Hamill et al., 1981). The patch electrodes were made of soft soda-lime capillary glass and had resistances of 2-5 $\mathrm{M} \Omega$ with internal solution before seal formation. The standard internal solution was composed of (in mM) $100 \mathrm{KCl}, 1 \mathrm{MgCl}_{2}$, $10 \mathrm{HEPES}, 10$ BAPTA, $3.6 \mathrm{Mg}$-ATP, 14 phosphocreatine, and 0.1 GTP plus $50 \mathrm{U} / \mathrm{ml}$ creatine phosphokinase, $\mathrm{pH}$-adjusted to 7.4 with $\mathrm{KOH}$. The extracellular solution was composed of (in mM) $140 \mathrm{NaCl}, 2 \mathrm{CaCl}_{2}, 1 \mathrm{MgCl}_{2}, 110$ glucose, and $5 \mathrm{KCl}$, $\mathrm{pH}$-adjusted to 7.4 with $\mathrm{NaOH}$. The osmolarity of the extracellular buffer solution and of the internal standard solution was adjusted to 310-320 mOsm and 290-300 mOsm with sucrose, respectively. After the resting membrane potential was measured, the neurons were hyperpolarized to $-70 \mathrm{mV}$ by constant current injection to standardize the current-clamp recording condition for subsequent voltage measurements. Four traces of action potentials were evoked by different current injection $(5,9,13$, and $17 \mathrm{pA}, 50 \mathrm{msec}$ ) every $30 \mathrm{sec}$, recorded with an Axopatch-1D amplifier (Axon Instruments, Foster City, CA), filtered at $2 \mathrm{kHz}$, and sampled at $10 \mathrm{kHz}$. pClamp6 (Axon Instruments) software was used during experiments and analysis. Changes in membrane potential produced by the chemokines or gp120 were monitored also, using a chart recorder (RS 3400 , Gould, Cleveland, OH). Drugs were applied by gravity via a continuous bath perfusion system at a flow rate of $1 \mathrm{ml} / \mathrm{min}$.

Immunohistochemical demonstration of chemokine receptor expression and quantification. The expression of CXCR4 and CCR4 by neonatal cultured rat DRG neurons was demonstrated immunohistochemically by using anti-human CXCR4 (hCXCR4, C20) or anti-mouse CCR4 (mCCR4, M-20) antiserum (Santa Cruz Biotechnology, Santa Cruz, Ca). Cross-reactivity of the respective rat chemokine receptors with hCXCR4 and mCCR4 antiserum was determined first in human embryonic kidney (HEK) 293 cells transiently expressing the rat chemokine receptor. Transient transfection was performed by using polyethyleniminemediated (PEI) transfection as described previously (Simen and Miller, 1998). HEK 293 cells grown on glass coverslips were fixed with $4 \%$ paraformaldehyde for $30 \mathrm{~min}$ at room temperature $2 \mathrm{~d}$ after transfection. Then the cells were permeated with $1 \%$ Triton X-100 in PBS for 5 min and blocked with $4 \%$ BSA for $1 \mathrm{hr}$, after which the cells were incubated with goat anti-hCXCR4 or anti-mCCR4 primary antisera diluted at 1:200 overnight at $4{ }^{\circ} \mathrm{C}$; immunoreactivity was visualized with incubation with an Alexa594-conjugated donkey anti-goat secondary antibody diluted at 1:500 (Molecular Probes) for $1 \mathrm{hr}$ at room temperature. Immunostaining without the primary antibodies or with peptide-preabsorbed antiserum was used as a negative control. Cultured rat neonatal DRG neurons were processed for immunostaining of CXCR4 and CCR4 essentially as described above.

The population of DRG neurons expressing CXCR4 or CCR4 receptors was investigated further by double-immunohistochemical staining. DRG neurons were incubated with substance P (rabbit anti-substance P antibody; RBI, Natick, MA) or VR1 antiserum (rabbit anti-VR1N; Guo et al., 1999) as well as hCXCR4 or mCCR4 antiserum, after which they were visualized with secondary antibodies conjugated with Alexa 594 (Molecular Probes) for CXCR4/CCR4 and FITC (Jackson ImmunoResearch, West Grove, PA) for substance P/VR1, respectively. The colocalization of these chemokine receptors with substance P or VR1 was examined by confocal-scanning laser microscopy with the Fluoview Confocal System (Olympus, Melville, NY) on an Olympus IX70 inverted microscope with a $60 \times$ oil immersion objective (Olympus, 1.4 numerical aperture). After the expression of chemokine receptors and their colocalization with substance P or VR1 was confirmed, DRG neurons expressing CXCR4 or CCR4, as well as those coexpressing substance $\mathrm{P}$ or VR1 with CXCR4 or CCR4, were quantified. The number of immunoreactive cells was counted manually in five spatially segregated fields randomly chosen on the coverslip. Immunostaining for neuron-specific enolase (Polysciences, Warrington, PA) was used to identify the total number of DRG neurons.

Determination of substance P release from cultured DRG neurons. Neonatal DRG neurons prepared as described above were plated on 12-well tissue culture plates at a density from 50,000 to $\sim 100,000$ cells/well, which had been coated previously with polyornithine and laminin. At $6 \mathrm{~d}$ in vitro (6 DIV), $50 \mathrm{nM}$ MDC or RANTES or $200 \mathrm{pm}$ gp120 HIV-1 ${ }_{\text {III }}$ was applied for $30 \mathrm{~min}$ to each well, together with the peptidase inhibitor $10 \mu \mathrm{M}$ phosphoramidon (Sigma). Then the supernatant from each well was collected and freeze dried until its assay with a substance P enzyme immunoassay kit (Cayman Chemical, Ann Arbor, MI). Substance P releases evoked by $1 \mu \mathrm{M}$ bradykinin (BK), $1 \mu \mathrm{M}$ capsaicin, and $50 \mathrm{~mm}$ $\mathrm{KCl}$ were used as positive controls.

$m R N A$ preparation and reverse transcription-PCR (RT-PCR). Total RNA was prepared from neonatal cultured DRG neurons with Trizol reagent (Life Technologies) according to the manufacturer's instructions. Firststrand cDNA was synthesized via the Superscript Preamplification System (Life Technologies). Briefly, reverse transcription of $5 \mu \mathrm{g}$ of total RNA was performed with Superscript II reverse transcriptase $(1 \mu \mathrm{l}, 200 \mathrm{U} / \mu \mathrm{l})$ in the supplied buffer, RNasin (1 $\mu \mathrm{l}, 20 \mathrm{U} / \mu \mathrm{l}$; Promega), $10 \mathrm{~mm}$ dNTP $(1 \mu \mathrm{l}), 0.1$ 


\begin{tabular}{|c|c|c|c|}
\hline \multirow[b]{2}{*}{ Chemokines } & \multirow[b]{2}{*}{ Receptor selectivity } & \multicolumn{2}{|l|}{ Proportion of cells responding } \\
\hline & & Cultured neonatal DRGs (\%) & Acutely isolated adult DRGs (\%) \\
\hline RANTES & $\begin{array}{l}\text { CCR1, CCR3, } \\
\text { CCR5, CCR9 }\end{array}$ & $6(68 / 1085)$ & $14(10 / 74)$ \\
\hline MCP-1 & CCR2, CCR9 & $22(27 / 124)$ & \\
\hline Eotaxin & CCR3 & $15(67 / 436)$ & \\
\hline TARC & CCR4 & $30(46 / 154)$ & \\
\hline MDC & CCR4 & $11(73 / 689)$ & $6(5 / 88)$ \\
\hline MIP-1 $\beta$ & CCR5, CCR9 & $12(15 / 126)$ & \\
\hline LARC & CCR6 & $12(12 / 97)$ & \\
\hline SLC & CCR7 & $36(25 / 70)$ & \\
\hline I-309 & CCR8 & $8(18 / 230)$ & \\
\hline IL-8 & CXCR1, CXCR2 & $5(16 / 351)$ & \\
\hline IP-10 & CXCR3 & $12(11 / 95)$ & \\
\hline SDF- $1 \alpha$ & CXCR4 & $30(48 / 160)$ & $6(10 / 154)$ \\
\hline BCA-1 & CXCR5 & $31(22 / 70)$ & \\
\hline Fractalkine & CX3CR1 & $9(79 / 911)$ & \\
\hline gp120 HIV & CXCR4 & $6(26 / 415)$ & $9(11 / 128)$ \\
\hline gp120 SIV mac251 $_{1}$ & CCR5 & $11(24 / 219)$ & $8(3 / 36)$ \\
\hline VMIP-I & CCR8 & $9(16 / 169)$ & \\
\hline VMIP-II & CCR3, CCR8 & $12(20 / 169)$ & \\
\hline VMIP-III & CCR4 & $4(4 / 98)$ & \\
\hline Capsaicin & & $55(268 / 487)$ & $76(120 / 157)$ \\
\hline Bradykinin & & $53(223 / 417)$ & $7(11 / 152)$ \\
\hline ATP & & $84(124 / 148)$ & \\
\hline
\end{tabular}

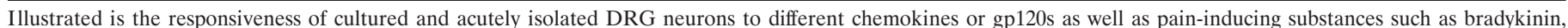

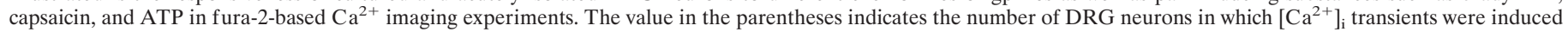

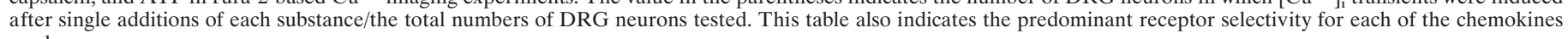
used.

M DTT $(2 \mu \mathrm{l})$, and oligo-dT oligonucleotide $(2 \mu \mathrm{l}, 0.5 \mu \mathrm{g} / \mu \mathrm{l})$ in a total volume of $20 \mu \mathrm{l}$ at $42^{\circ} \mathrm{C}$. After reverse transcription, RNase $\mathrm{H}(1 \mu \mathrm{l}, 2 \mathrm{U} / \mu \mathrm{l})$ was used to degrade the remaining RNA bound to the cDNA. PCR reaction was performed with $2 \mu \mathrm{l}$ of the resulting cDNA by using Elongase DNA polymerase (Life Technologies); primers for PCR were designed specifically for each chemokine receptor, based on GenBank rat cDNA sequences. PCR reactions with cDNA from both rat brain and water were run in parallel as positive and negative controls, respectively. The following primers (forward/reverse) were used for the amplification of chemokine receptors: CXCR4 (GGTCTGGAGACTATGACTCCA/GTGCTGGAACTGGAACACCA), CX3CR1 (TCCCGGAATTGGATCTAGAG/ GCAGGACCTCGGGGTAATCA), CCR4 (CAGGATGAAGCCGCGTACAAT/GTGATGAGGCTGGTGATGACC), and CCR5 (GTATGTCAGCACCCTGCCAA/AAGATGAGCCTTACAGCCCTG).

Pain testing. Responsiveness to punctate tactile stimuli was determined in male Sprague Dawley rats (275-325 gm; Sasco, Kingston, NY) by using von Frey filaments (Stoelting, Chicago, IL). First the animals were acclimated to a Plexiglas testing chamber, the floor of which was constructed of wire mesh. von Frey filaments of logarithmic incremental stiffness (1.5-75 gm; Stoelting) were applied perpendicularly to the midplantar surface of the hindpaw in the immediate vicinity of the designated injection site with enough force to cause the filament to bend. In the absence of a paw withdrawal, the filament one log value higher was applied. If the paw was withdrawn, a positive response was recorded and the filament one log value below was applied. After the first "crossover" from a negative to a positive response or vice versa, five additional presentations of stimuli were made. Then the threshold for response was calculated as described by Chaplan et al. (1994). After determination of baseline mechanical threshold, an intradermal injection of saline, $500 \mathrm{ng}$ of BK, or $250 \mathrm{ng}$ of RANTES, SDF- $1 \alpha$, MDC, gp120 HIV-1 $1_{\text {IIIB }}$, or

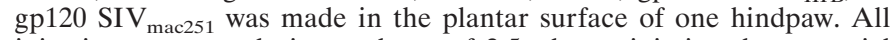
injections were made in a volume of $2.5 \mu \mathrm{l}$ to minimize the potential confound of inflammation and mechanical disruption. Then the mechanical threshold was redetermined 10, 20,30, 60, 90, 120, and 180 min later. The effects of drug were compared with those of vehicle by a two-way repeated measures ANOVA. Post hoc comparisons between treatment group mean values were made by Newman-Keuls tests. These experiments were approved by the Institutional Animal Care and Use Committee of the University of Chicago.

\section{RESULTS}

\section{Chemokines activate $\left[\mathrm{Ca}^{2+}\right]_{i}$ signals in DRG neurons}

Activation of chemokine receptors expressed by leukocytes, cell lines, and hippocampal neurons results in the mobilization of internal $\mathrm{Ca}^{2+}$ stores (Baggiolini et al., 1994; Meucci et al., 1998; Zheng et al., 1999). We therefore examined the effects of a diverse set of chemokines on $\left[\mathrm{Ca}^{2+}\right]_{\mathrm{i}}$ in cultured neonatal rat DRG neurons as a screen for the presence of functional chemokine receptors. These chemokines were selected so as to activate a wide spectrum of chemokine receptors (Table 1). Ca mobilization was used in this instance strictly as an indication of chemokine receptor activation and does not necessarily imply a role for this phenomenon in the other physiological effects of chemokines described below. The concentration of chemokines or gp120s used in this experiment was based on our previous observations of their effects on $\mathrm{Ca}$ mobilization in hippocampal neurons (Meucci et al., 1998). The application of vehicle at the beginning of experiment (i.e., $10 \mu \mathrm{l}$ of $0.1 \% \mathrm{BSA} / \mathrm{PBS}$ in $1 \mathrm{ml}$ of BSS) did not alter $\left[\mathrm{Ca}^{2+}\right]_{\mathrm{i}}$ (data not shown). However, as shown in Figures 1 and 2 and Table 1, the subsequent application of all of the chemokines we tested increased $\left[\mathrm{Ca}^{2+}\right]_{\mathrm{i}}$ in populations of DRG neurons. Although the percentages of DRG neurons responding to chemokines were variable, chemokines acting on all three families of chemokine receptors [i.e., CXCR $(\alpha$-chemokine receptor), $\mathrm{CCR}$ ( $\beta$-chemokine receptor), CX3CR ( $\delta$-chemokine receptor)] clearly mobilized $\left[\mathrm{Ca}^{2+}\right]_{\mathrm{i}}$. Furthermore, DRG neurons 
A

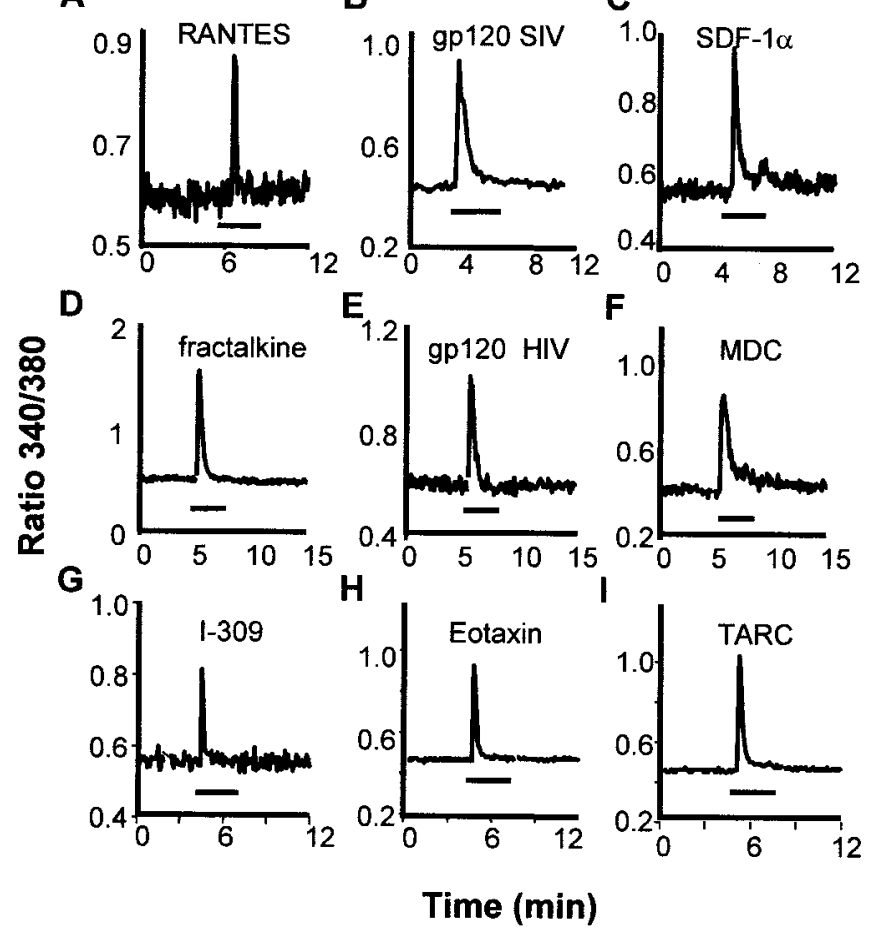

Figure 1. Chemokines and gp120s increased $\left[\mathrm{Ca}^{2+}\right]_{\mathrm{i}}$ in single cultured rat DRG neurons. This figure illustrates examples of responses to individual applications of several chemokines. The complete list of chemokines tested in this paradigm is provided in Table 1. gp120 SIV $\mathrm{Smac251}_{\text {- }}$ selective for CCR5, gp120 HIV-1 ${ }_{\text {III B }}$ selective for CXCR4, and chemokines that activate different CCRs (RANTES, MDC, TARC, eotaxin, I-309), CXCR4 (SDF-1 $\alpha$ ) as well as CX3CR1 (fractalkine) were applied for the time indicated by the bars $(3 \mathrm{~min})$. Concentrations of chemokines that were applied included RANTES (50 nM), gp120 SIV $\operatorname{mac}_{\text {ma }}(200 \mathrm{pM})$, SDF-1 $\alpha(50 \mathrm{nM})$, fractalkine $(100 \mathrm{nM})$, gp120 HIV-1 ${ }_{\text {III B }}(200 \mathrm{pM})$, MDC (50 nM), I-309 (50 nm), eotaxin (50 nm), and TARC (50 nM).

also responded to three chemokines (vMIP-I, II, and III) synthesized by Kaposi's sarcoma herpes virus (Human herpes virus-8, HHV-8), which exert both agonist and antagonist effects at a variety of chemokine receptors (Dittmer and Kedes, 1998). We also tested the effects of two different types of gp120, gp120 SIV $_{\text {mac251 }}$ and gp120 HIV-1 $1_{\text {III }}$, that are selective for CCR5 and CCR4, respectively (Horuk, 1999). Both types of gp120 increased $\left[\mathrm{Ca}^{2+}\right]_{\mathrm{i}}$ in populations of DRG neurons, consistent with the fact that they can bind to, and sometimes also activate, certain chemokine receptors (Fig. 1, Table 1) (Weissman et al., 1997; Meucci et al., 1998; Horuk, 1999; Miller and Meucci, 1999; Vlahakis et al., 2001). To confirm that the chemokine effects on $\left[\mathrm{Ca}^{2+}\right]_{i}$ were attributable to direct actions on DRG neurons and not attributable to any non-neuronal cells present in the culture, we also examined the effects of all chemokines and gp120s on fibroblasts, which were the major non-neuronal cells contaminating our cultures. These cells are easily distinguishable from DRG neurons by their characteristic flattened shapes. Neither chemokines nor gp120 produced any change in $\left[\mathrm{Ca}^{2+}\right]_{i}$ in these cells.

Although we did not examine the effects of every chemokine on every neuron, it is clear that many neurons responded to more than one chemokine, even if they were agonists at different types of chemokine receptors. After investigating the effects of up to three chemokines on each neuron, we observed significant heterogeneity in inducing $\left[\mathrm{Ca}^{2+}\right]_{\mathrm{i}}$ responses (Fig. 2). For example, $53 \%$ of the chemokine-responsive DRG neurons responded to

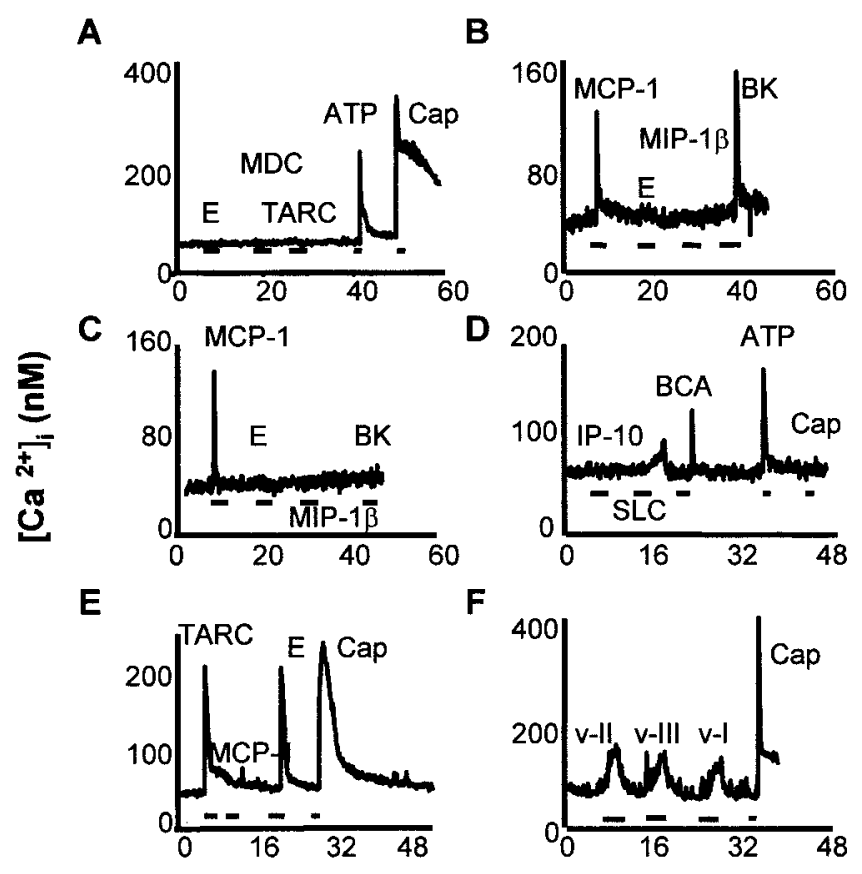

Time (min)

Figure 2. DRG neurons exhibited complex patterns of responsiveness to chemokines in a fura-2-based calcium-imaging experiment. This figure shows examples of responsiveness of individual DRG neurons to combinations of chemokines. Note that chemokine-responsive neurons were also frequently responsive to known excitants of nociceptive neurons such as bradykinin, capsaicin, or ATP. However, this was not inevitably the case (e.g., compare $B, C$ ). Concentrations of molecules that were applied in these studies were eotaxin $(E ; 50 \mathrm{~nm})$, MDC (50 nM), TARC (50 nM), MCP-1 (50 nM), MIP-1 $\beta$ (50 nM), IP-10 (50 nM), SLC (50 nM), BCA (50 nM), VMIP-I (v-I, $100 \mathrm{nM})$, VMIP-II $(v-I I, 100 \mathrm{nM})$, VMIP-III $(v-I I I, 100$ $\mathrm{nM})$, bradykinin $(B K, 1 \mu \mathrm{M})$, capsaicin $($ Cap, $1 \mu \mathrm{M})$, and ATP $(100 \mu \mathrm{M})$.

one chemokine, $40 \%$ to two, and $7 \%$ to all three chemokines ( $n=$ 164). This heterogeneous response was not limited to neonatal DRG neurons because acutely isolated DRG neurons from mature rats also showed similar responses to both chemokines and gp120s (Table 1). These results suggest that differential expression of chemokine receptors exists in subpopulations of DRG neurons.

It is clear that a majority of neurons $(84.7 \%)$ that were sensitive to chemokines and gp120s corresponded to nociceptors, because the same neurons also responded to the application of capsaicin, bradykinin (BK), or ATP (Fig. 2, Table 1), substances for which the effects typically are used as markers for nociceptive neurons (Cesare and McNaughton, 1996; Caterina et al., 1997; Gu and MacDermott, 1997). Only $14.3 \%$ of BK-, capsaicin-, or ATPresponsive neurons did not exhibit sensitivity to chemokines or gp120. Furthermore, when we performed experiments on acutely isolated neurons from adult rats, $100 \%$ of the cells that responded to chemokines or gp120s also responded to capsaicin or BK (Table 1). Nevertheless, chemokine sensitivity clearly was not restricted to nociceptive DRG neurons because we also observed examples of chemokine-sensitive neurons $(9.1 \%)$ that did not respond to capsaicin, ATP, or BK (e.g., Fig. 2, compare $B$ with $C$ ). In conclusion, although the precise identity of all of the chemokine receptors that are expressed by DRG neurons is not known with certainty, it appears that nociceptive neurons express many types of chemokine receptors, allowing them potentially to re- 


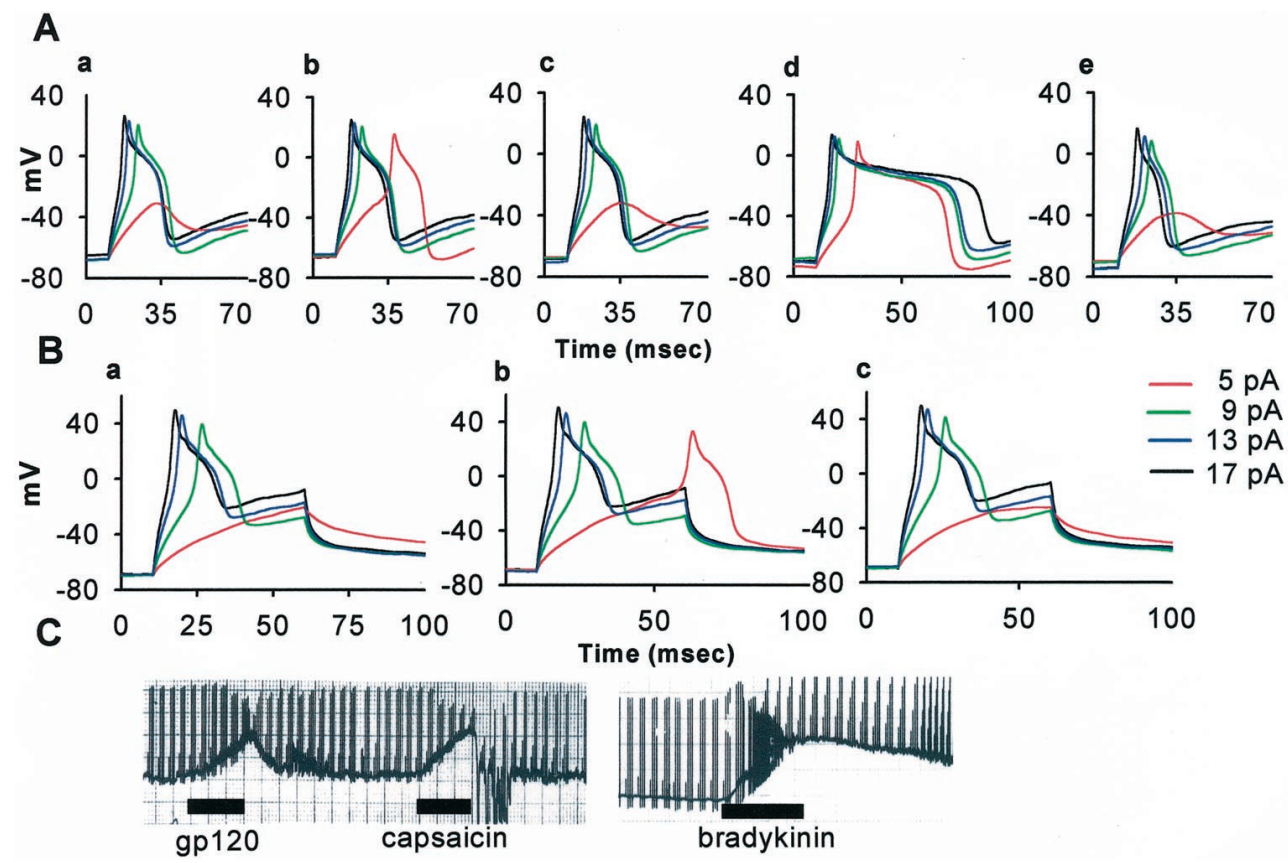

Figure 3. Chemokines and gp120s excite DRG neurons. $A$, Illustrated are the effects of the chemokine MDC on the neuronal spike threshold. The neuron was unable to fire an action potential when $5 \mathrm{pA}$ of current was injected under normal conditions (a) but did so, in a reversible manner, 2 min after the addition of MDC $(b)$. Note that MDC did not change the membrane potential. Note also that this neuron was excited by capsaicin $(d)$, indicating its identity as a nociceptive neuron. $c$, $e$, Illustrated is the washout of the effects of MDC and capsaicin, respectively. $B$, In this case the addition of gp120 lowered the spike threshold in this neuron, again without depolarizing the neuron ( $a$, control; $b, 2$ min after the addition of gp120 $\mathrm{SIV}_{\text {mac251 }}$; $c$, after washout of the gp120). $C$, In some neurons, such as this example, gp120s or chemokines produced clear depolarization of the cell. Note that this neuron also was depolarized by capsaicin and bradykinin. A total of 20 neurons of 79 that were tested exhibited excitatory responses (MDC, 3 of 7; fractalkine, 1 of 7 ; SDF- $1 \alpha, 1$ of 7 ; eotaxin, 3 of 8; VMIP-2, 1 of 7; TARC, 1 of 7 ; gp120 SIV $_{\operatorname{mac} 251}, 5$ of $16 ;$ gp120 HIV$1_{\text {IIIB }}, 4$ of 14; RANTES, 1 of 7). In these cells the chemokines or gp120 lowered the threshold without changing the membrane potential $(45 \%$; $n=9)$ or depolarized DRG neurons $(55 \% ; n=11)$. Of the chemokine- or gp120-responsive neurons $70 \%(n=14)$ also responded to capsaicin. Concentrations of chemokines that were applied included MDC (50 nM), fractalkine (100 nM), eotaxin (50 nM), VMIP-II (100 nM), TARC (50 nM), gp120 SIV mac251 (200 pM), gp120 HIV-1 ${ }_{\text {IIIB }}(200 \mathrm{pM})$, capsaicin $(1 \mu \mathrm{M})$, and BK $(1 \mu \mathrm{M})$.

spond to a wide variety of chemokines. Furthermore, the patterns of chemokine sensitivity displayed by DRG neurons appear to be highly complex.

\section{Chemokines produce excitation of DRG neurons}

The effects of the chemokines on DRG neurons resemble those of $\mathrm{BK}$, which also produces $\mathrm{Ca}^{2+}$ mobilization in these neurons by activating a GPCR (Bleakman et al., 1990). BK has been shown to excite these neurons powerfully and acts as an important mediator of pain that is associated with inflammation and other disease states (Levine et al., 1993; Cesare and McNaughton, 1996). We therefore performed current-clamp recordings on DRG neurons to see whether chemokines also would produce excitatory effects. Two types of excitatory responses were observed (Fig. 3). In some cells we found that chemokines (Fig. 3A) or gp120s (Fig. 3B) lowered the threshold for action potential generation without changing the membrane potential. These changes in action potential threshold reversed after washout of the agonist. In other instances we observed that chemokines or gp120s reversibly depolarized DRG neurons (Fig. $3 C$ ). As in the case of the $\mathrm{Ca}^{2+}$ measurements, the majority of the neurons that responded to chemokines or gp120s also responded to capsaicin, indicating that they were nociceptors. In contrast, only $12 \%$ of DRG neurons that did not respond to chemokines or gp120s were capsaicin-sensitive. Although we did not examine all of the chemokines that we had tested in the $\mathrm{Ca}^{2+}$ mobilization experiments, excitatory responses were observed with a variety of chemokines, including MDC, fractalkine, TARC, eotaxin, RANTES, SDF1- $\alpha$, and vMIP-II as well as gp120 HIV-1 ${ }_{\text {III B }}$ and gp120 SIV $_{\text {mac251. }}$.

\section{Immunohistochemical localization of chemokine receptors on DRG neurons}

The ability of the chemokines, gp120 HIV-1 $1_{\text {IIIB }}$, and gp120 SIV $_{\text {mac251 }}$ to increase $\left[\mathrm{Ca}^{2+} \mathrm{i}\right.$ ] and to excite DRG neurons suggests that DRG neurons express chemokine receptors. Further evidence in support of this conclusion was provided by immunohistochemical methods. Given that at least 18 different chemokine receptors have been identified (Murphy et al., 2000), it was not feasible to examine the distribution of each receptor type. We selected the CXCR4 receptor to study because it is the receptor for both the chemokine SDF- $1 \alpha$ and also gp120 HIV-1 $1_{\text {III B }}$. We also studied the CCR4 receptor as an example of the CC family of chemokine receptors. Figure $4, A$ and $B$, illustrates that the antiserum that was used produced specific staining of the rat CXCR4 receptor. Of the DRG neurons that were stained positively for neuron-specific enolase, $48.3 \%$ expressed CXCR4 receptors $(n=645)$. Staining for the CXCR4 receptor was apparent in the DRG soma and particularly in terminal varicosities (Fig. $4 B, C)$, suggesting that peripheral terminals of DRG neurons expressing CXCR4 receptors may interact with chemokines released in inflamed tissue. Specific staining for the CCR4 receptor also was observed on a population of DRG cells (Fig. $5 A$ ). In this case $13.2 \%$ of enolase-positive neurons costained for CCR4 receptors $(n=704)$. Because the $\left[\mathrm{Ca}^{2+}\right]_{\mathrm{i}}$ imaging and electrophysiological studies had indicated that many chemokine-sensitive cells also responded to capsaicin, we next examined whether the CXCR4 and CCR4 receptors colocalized with the capsaicin receptor (vanilloid receptor VR1). In all, 71\% of CXCR4-positive neurons also stained positively for VR1 (see Fig. $4 D ; n=579$ ), and $58.1 \%$ of CCR4-positive neurons stained for VR1 (Fig. $5 C$; $n=496)$. The majority of CXCR4-positive $(91.5 \% ; n=809)$ and CCR4-positive $(89.6 \% ; n=538)$ cells also stained for substance $\mathrm{P}$ (see Figs. $4 C, 5 B)$.

Because proinflammatory substances such as bradykinin, which can activate DRG neurons directly, have been shown to stimulate substance P release from cultured DRG neurons (Vasko et al., 1994), we next examined whether chemokines or gp120 causes the release of substance $P$ from cultured neonatal DRG neurons. The addition of chemokines or gp120 HIV-1 ${ }_{\text {III B }}$ to DRG cultures 

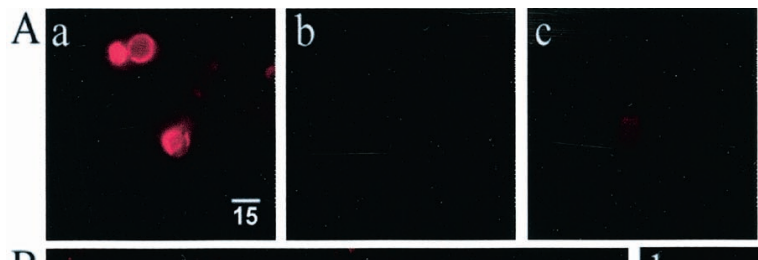

$\mathrm{B}$ a
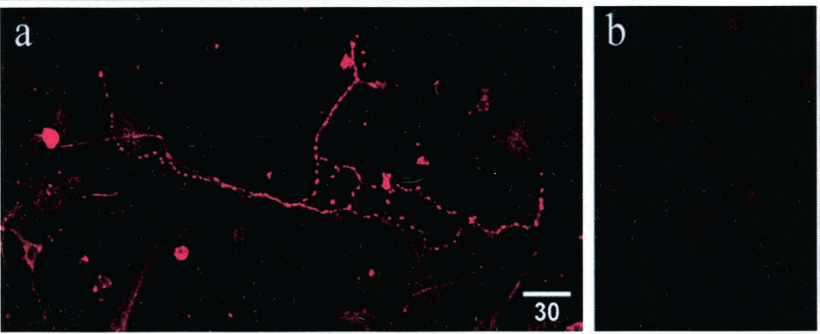

Ca
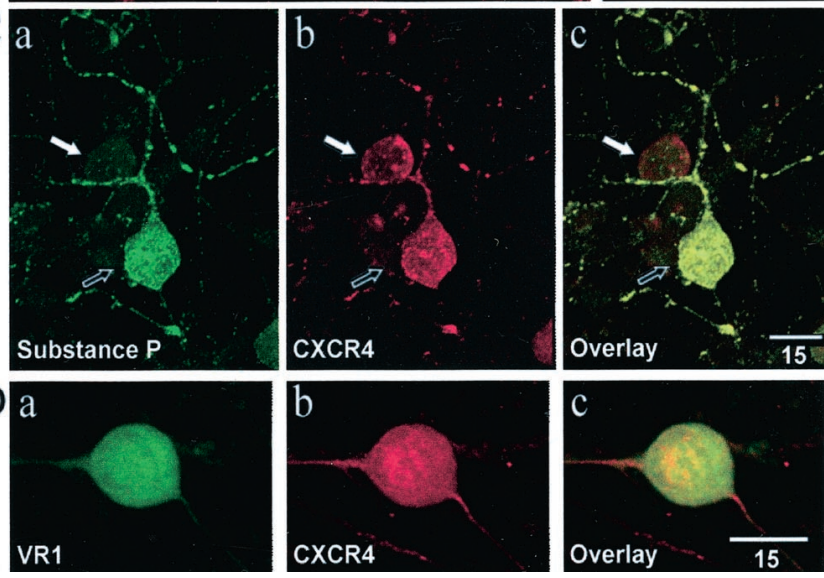

Figure 4. Confocal laser microscopy analysis of CXCR4 expression on HEK 293 cells and DRG neurons. $A$, Illustrated is immunohistochemical staining for the cloned rat CXCR4 receptor expressed in HEK 293 cells (a). Also illustrated are controls in which the primary antibody was not applied (b) or HEK 293 cells in which the receptor was not expressed $(c)$. $B$, Staining of cultured rat DRG cells revealed a population of neurons that expressed the CXCR4 receptor $(a)$. Note the staining of both the cell soma and terminal varicosities. Staining for the CXCR4 receptor could be blocked by preabsorbing the antiserum with the peptide epitope against which it was raised $(b) . C$, Colocalization of substance $\mathrm{P}$ and the CXCR4 receptor in rat DRG neurons. $a, \mathrm{DRG}$ neuron staining for substance P. $b$, Two DRG neurons staining for the CXCR4 receptor. $c$, Overlay of images in $a$ and $b$ showing the colocalization of substance $\mathrm{P}$ and the CXCR4 receptor in one neuron (black arrow) and the absence of substance $\mathrm{P}$ (white arrow) in the second CXCR4-stained neuron. D, Colocalization of VR1 and the CXCR4 receptor in rat DRG neurons. $a, \mathrm{DRG}$ neuron staining for VR1. $b$, Staining for CXCR4. $c$, Overlay of images in $a$ and $b$ showing the colocalization of VR1 and the CXCR4 receptor.

stimulated significant substance $\mathrm{P}$ release into the culture medium (Fig. 5D), although bradykinin was more effective in this regard. Both high $\left[\mathrm{K}^{+}\right]$and capsaicin produced very high levels of substance $\mathrm{P}$ release in these cultures.

\section{Molecular biological investigation of chemokine receptors expressions on DRG neurons}

RT-PCR was performed to provide further evidence that DRG neurons express different types of chemokine receptors. Total RNA extracted from neonatal cultured DRG neurons was used for all PCR reactions. After reverse transcription the resulting cDNA was amplified by PCR, using primers designed specifically to detect members of three different families of chemokine receptors: CXCR4 for the CXCR receptor family, CX3CR1 for the CX3CR receptor family, and CCR4, CCR5 for the CCR receptor

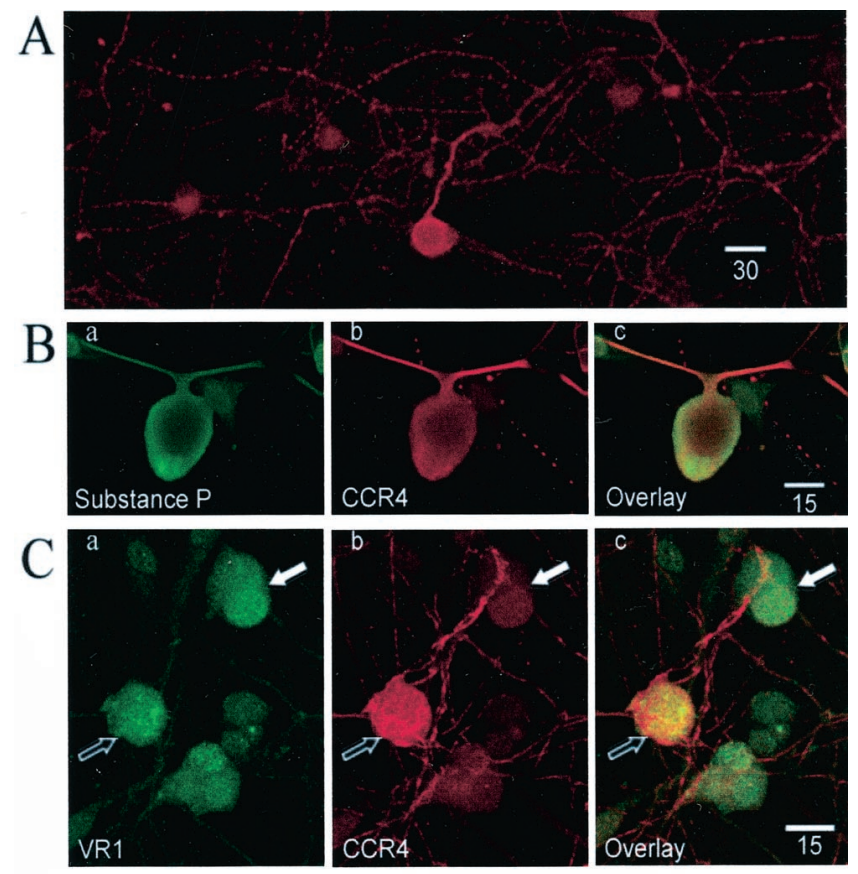

D

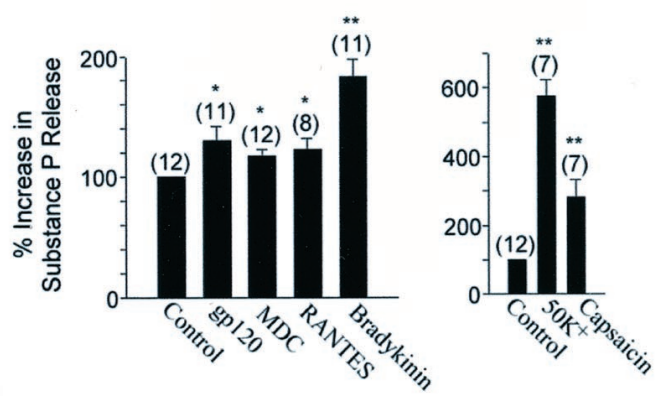

Figure 5. Confocal laser microscopy analysis of CCR4 expression on DRG neurons. $A$, Staining with anti-mouse CCR4 antiserum demonstrated the expression of CCR4 receptor in a population of neurons from cultured rat DRG cells. $B$, Colocalization of substance P and the CCR4 receptor in rat DRG neurons. $a$, DRG neuron staining for substance P. $b$, Staining for CCR4. $c$, Overlay of images in $a$ and $b$ showing the colocalization of substance P and the CCR4 receptor. $C$, Colocalization of VR1 and the CCR4 receptor in rat DRG neurons. $a$, DRG neuron staining for VR1. Three DRG neurons were stained positively for the VR1. $b$, Staining for CCR4. $c$, Overlay of images in $a$ and $b$ showing the colocalization of VR1 and the CCR4 receptor in one neuron (black arrow) and absence of CCR4 (white arrow) in the second VR1-stained neuron. $D$, Left, The effect of MDC, RANTES, gp120 HIV-1 ${ }_{\text {IIIB }}$, and bradykinin on substance P release from cultured neonatal DRG neurons. D, Right, The effects of $50 \mathrm{mM} \mathrm{K}^{+}$and $1 \mu \mathrm{M}$ capsaicin used as positive controls. ${ }^{*} p<0.05$; ${ }^{* *} p<0.01$.

family. The sizes of the amplified products were (in bp) 560 for CXCR4, 540 for CX3CR1, 432 for CCR4, and 670 for CCR5, respectively, which were consistent with the predicted sizes (Fig. 6). Rat brain used as a positive control also demonstrated the presence of chemokine receptors.

\section{Chemokines induce allodynia}

The ability of chemokines and gp120s to excite nociceptive neurons suggests that they might produce pain. We therefore also examined whether intradermal injection of BK, gp120 HIV-1 ${ }_{\text {III B }}$, gp120 SIV mac251 $_{1}$, MDC, RANTES, or SDF-1 $\alpha$ in the hindpaw of the rat would enhance responsiveness to punctate mechanical stimuli as determined by von Frey filaments (Chaplan et al., 

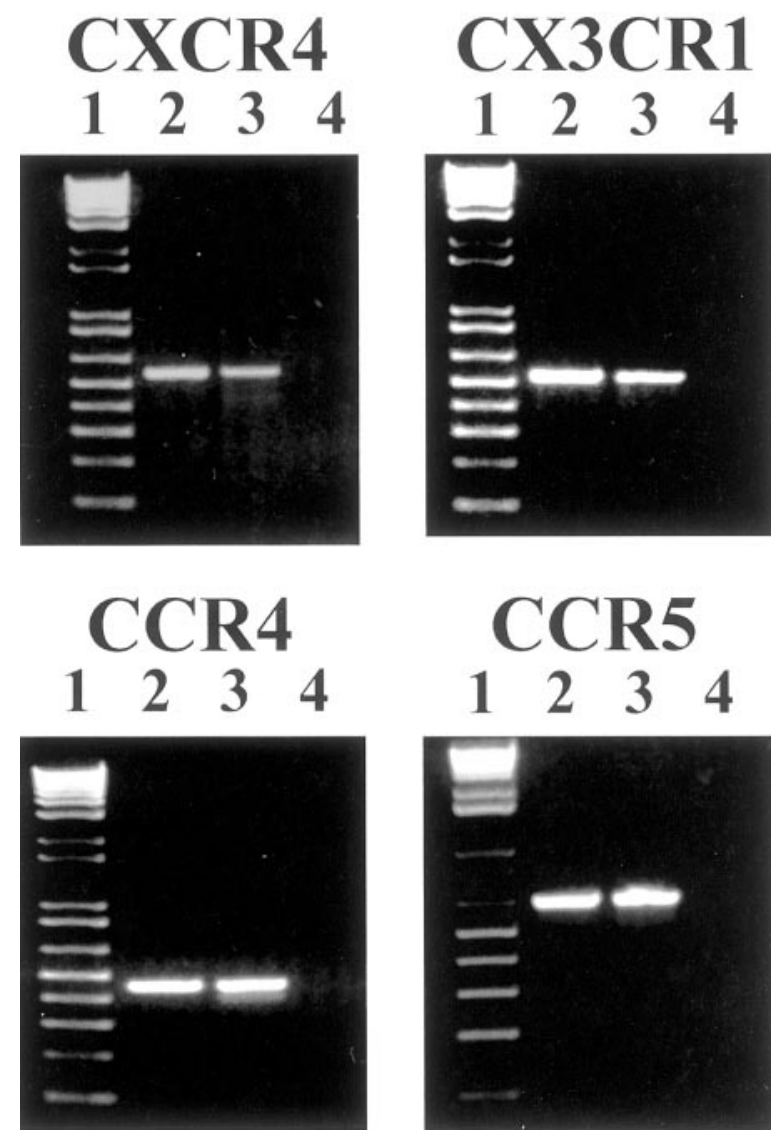

Figure 6. RT-PCR analysis of chemokine receptor expression on neonatal DRG neurons. Results demonstrate the presence of mRNA of CXCR4, CX3CR1, CCR5, and CCR4 in DRG neurons. Lanes 2 and 3 in each panel show PCR products obtained from amplification by primers selected specifically to detect each chemokine receptor (lane 2, DRG neurons; lane 3, rat brain). Lane 1 contains $1 \mathrm{~kb}$ plus ladder (Life Technologies); lane 4 indicates no amplification products with $\mathrm{H}_{2} \mathrm{O}$.

1994). Intradermal injection of vehicle in the plantar surface of the hindpaw caused a small, transient (20-30 min) increase in the threshold for paw withdrawal in response to von Frey filaments. In contrast, intradermal injection of $500 \mathrm{ng}$ of BK decreased the mechanical threshold within $10 \mathrm{~min}$. This tactile allodynia persisted for at least $2 \mathrm{hr}$ and began to dissipate by $3 \mathrm{hr}$ (Fig. 7A). Tactile allodynia of rapid onset also was produced by intradermal

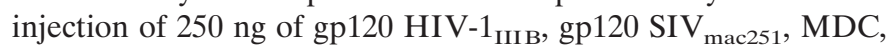
or SDF-1 $\alpha$ (Fig. $7 B$ ). The onset was precipitous, with maximal allodynia evident within $10 \mathrm{~min}$. Although the magnitude of the tactile allodynia did not differ among these four chemokines, rats that received SDF- $1 \alpha$ and BK exhibited exaggerated withdrawal responses. These rats maintained their paw in an elevated position for 1-2 min after application of the von Frey filament and often licked the paw for an extended period of time. Intradermal injection of gp120 HIV-1 $1_{\text {III B }}$ induced immediate and pronounced vocalization lasting 15-30 sec. Intradermal injection of $250 \mathrm{ng}$ of RANTES also produced tactile allodynia. However, this effect was not maximal until $30 \mathrm{~min}$ after injection, and its magnitude was less than that produced by either gp120 HIV-1 $1_{\text {III B }}$ or SDF-1 $\alpha$ (Fig. $7 B$ ). Intradermal injection of these chemokines in the hindpaw did not produce any obvious erythema or swelling during the subsequent $3 \mathrm{hr}$ observation period. Intradermal injection of 7.5 $\mu \mathrm{g}$ of capsaicin also produced tactile allodynia of comparable
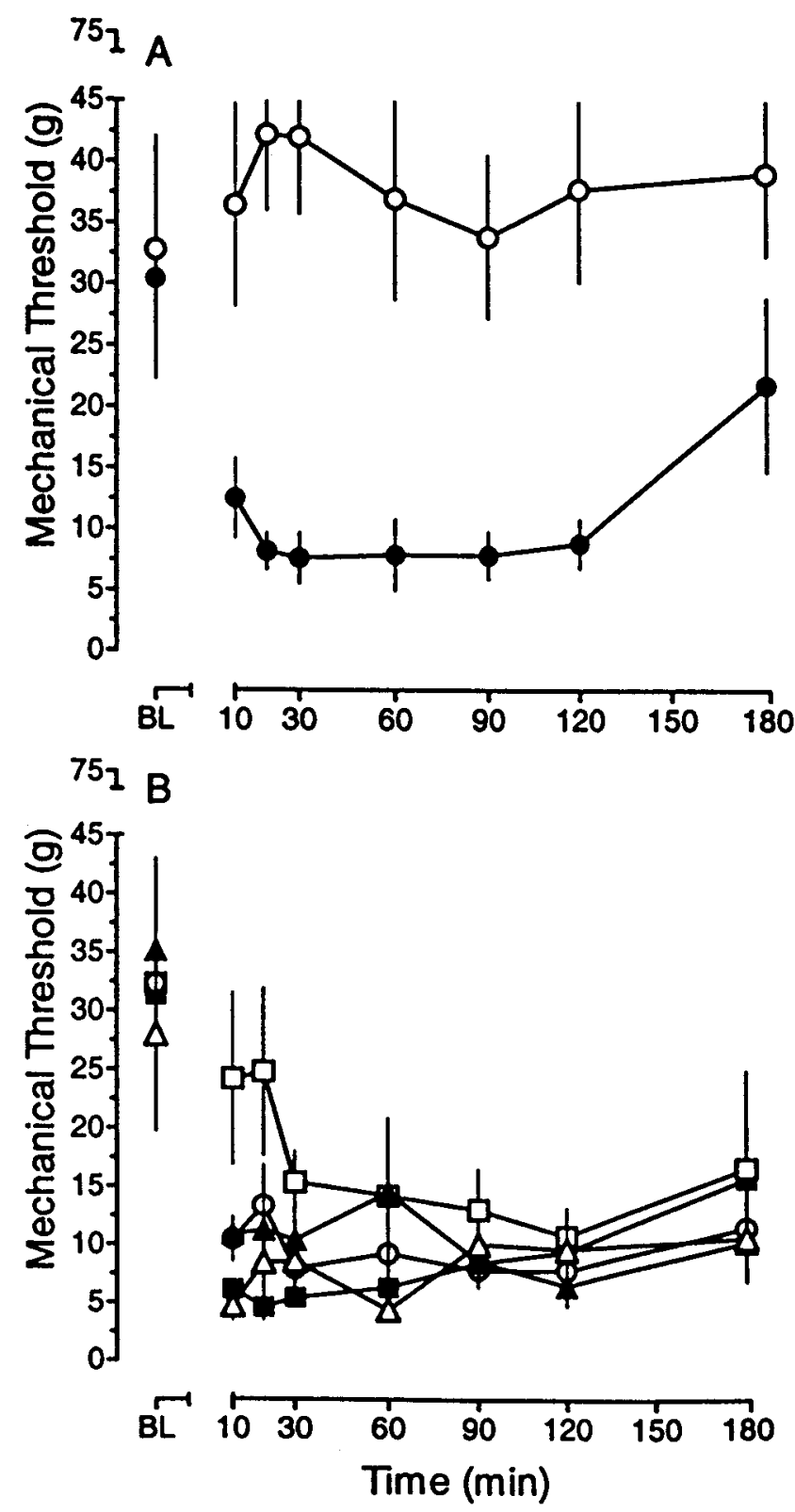

Figure 7. Chemokines and coat proteins produce tactile allodynia. $A$, The intradermal administration of $500 \mathrm{ng}$ of bradykinin ( ), but not the vehicle control $(\bigcirc)$, reduced the threshold to withdraw the hindpaw in response to punctate mechanical stimuli. $B$, The intradermal administration of $250 \mathrm{ng}$ of the chemokines RANTES $(\square)$, SDF-1 $\alpha(\boldsymbol{\square})$, and MDC $(\bigcirc)$ or the coat proteins gp120 $\operatorname{SIV}_{\operatorname{mac} 251}(\triangle)$ and gp120 HIV-1 III B $(\Delta)$ also reduced the mechanical threshold. $B L$, The mean baseline threshold before the intradermal injection. The symbols represent the mean \pm SEM from five to seven rats. Threshold values for all agents were significantly different from the corresponding time point in vehicle-treated rats; $p<$ 0.01 . These data were obtained concurrently and are presented in two panels for clarity of presentation.

magnitude, as well as additional spontaneous pain behaviors, in the absence of any obvious erythema or swelling (data not shown); $30 \mu \mathrm{g}$ similarly did not produce erythema or swelling (data not shown; D. A. Simone, personal communication).

\section{DISCUSSION}

Patients infected with the HIV-1 virus suffer from a wide variety of chronic pain syndromes and peripheral neuropathies, although 
the reasons for this are unknown (Brannagan et al., 1997; Hewitt et al., 1997; Griffin et al., 1998; Bouhassira et al., 1999). Now it is becoming clear that neurons express a wide variety of chemokine receptors. Indeed, chemokines and their receptors are expressed by all of the major cell types throughout the nervous system (i.e., neurons, glia, and microglia; Miller and Meucci, 1999). Thus chemokines may play a variety of roles in the nervous system in addition to the immune system. In support of this possibility, chemokines have been reported to produce a number of shortterm effects on synaptic transmission as well as long-term effects on neuronal survival (Meucci et al., 1998, 2000; Miller and Meucci, 1999; Zheng et al., 1999; Limatola et al., 2000).

Bolin et al. (1998) demonstrated that RANTES could produce a $\left[\mathrm{Ca}^{2+}\right]_{\mathrm{i}}$ increase in DRG neurons and also could act as a chemotactic factor for these cells. Our results now demonstrate that nociceptive neurons express a very wide variety of functional chemokine receptors. The activation of chemokine receptors on DRG neurons produced a number of responses that are reminiscent of the effects of $\mathrm{BK}$, including $\mathrm{Ca}^{2+}$ mobilization, neuronal excitation, substance $\mathrm{P}$ release, and allodynia (Bleakman et al., 1990; Cesare and McNaughton, 1996; Dray, 1997). Why DRG neurons respond to such a wide variety of chemokines is not clear at this point. It is possible that chemokines may act as a messenger between peripheral immune cells and sensory afferent neurons at inflamed sites. It has been shown that immune/inflammatory insults produce large changes in neural activity and consequent physiological and behavioral responses, including the activation of the hypothalamus-pituitary-adrenal (HPA) axis (Chrousos, 1998). Proinflammatory cytokines such as IL-1, IL-6, and TNF- $\alpha$ have been shown to be involved in this mechanism, but the pathways that they use are still controversial (Goehler et al., 1999). Because axon terminals of DRG widely express CXCR4 receptors (see Fig. $4 B$ ), they may be able to respond to signals generated by peripheral immune cells and deliver them to brain via ascending spinal routes. In addition, it is also possible that they participate in neurogenic inflammation via axon-reflex loops as chemokines elicit substance $\mathrm{P}$ release from the cultured DRG neurons (see Fig. 5D). Furthermore, the colocalization of these receptors with substance P and VR1, the fact that many chemokine sensitive cells are also sensitive to substances like capsaicin, bradykinin, and ATP, and the observations that chemokines produce allodynia lead us to propose that chemokines may act as proinflammatory cytokines.

Although we cannot exclude completely the possibility that the effects of chemokines on DRG neurons might be mediated indirectly via non-neuronal cells, several pieces of evidence argue against this possibility. First, chemokines did not induce $\left[\mathrm{Ca}^{2+}\right]_{i}$ mobilization in non-neuronal cells. Second, positive staining for CXCR4 and CCR4 was detected only in neuronal cells. Third, a majority of cells in the cultures were DRG neurons. Last, the patch-clamp recordings were performed on replated DRG neurons after all other non-neuronal cells had been removed. Taken together, these data strongly suggest that chemokines can act directly at chemokine receptors on DRG neurons.

It is interesting to note that a higher percentage of cells stained positively for the CXCR4 receptor (48.3\%) than exhibited $\left[\mathrm{Ca}^{2+}\right]_{\mathrm{i}}$ signals $(30 \%)$ in response to SDF-1 $\alpha$. We have observed that in some cells a high percentage of the staining for CXCR4 is localized intracellularly and that expression of GFP-tagged CXCR4 receptors in DRG neurons targets the receptor to both the plasma membrane or intracellularly, depending on the conditions (our unpublished observations). Thus it is possible that, in some of the CXCR4-positive cells, the receptors are uncoupled from signaling to intracellular $\mathrm{Ca}^{2+}$ stores. Indeed, CXCR4 receptors, like other GPCRs, are being recycled constantly to intracellular compartments and back to the cell membrane as a mechanism for adjusting the sensitivity of cells to agonists (Ferguson et al., 1998).

It is also interesting to note that in DRG, as in other types of neurons and leukocytes, gp120s can produce agonist-like effects (Weissman et al., 1997; Vlahakis et al., 2001). However, exactly how these effects are produced is unclear. In human leukocytes gp120 HIV-1 $1_{\text {III в }}$ produces its effects primarily via combinations of the CXCR4 receptor and the CD4 molecule. One hypothesis therefore might be that the effects of gp120 HIV-1 ${ }_{\text {III B }}$ observed on DRG neurons are mediated by the CXCR4 receptor. However, it should be pointed out that, although rat CXCR4 receptors can substitute for human receptors as coreceptors for gp120

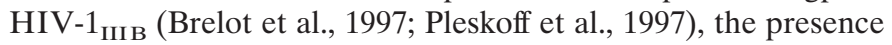
of the human CD4 molecule is essential for a high-affinity interaction to occur. Because rat DRG do not express human CD4 molecules, it is unlikely that high-affinity interactions of this type can occur. Two other hypotheses should be considered also. The first is that gp120 HIV-1 ${ }_{\text {II B }}$ interacts with the rat CXCR4 receptor in a CD4 "independent" manner (Hesselgesser et al., 1997). This could be a low-affinity interaction or else a higher-affinity interaction involving a coreceptor other than human CD4. As a result of these interactions gp120 HIV-1 $1_{\text {III }}$ might elicit lowefficacy partial agonist effects. Another possibility is that gp120 HIV-1 $1_{\text {III B }}$ elicits its effects via a GPCR other than the CXCR4 receptor. Indeed, there are other potential gp120 receptors, such as the apelin receptor, that are highly expressed in the nervous system (Choe et al., 2000). Whatever the precise mechanism, it is clear that gp120 produces chemokine-like effects on rat DRG and that these effects may well underlie its ability to produce pain.

The current behavioral data do not permit a direct comparison of the potencies of SDF- $1 \alpha$, RANTES, MDC, gp120 HIV-1 ${ }_{\text {II B }}$,

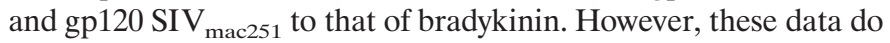
indicate that all three chemokines and the gp120 coat proteins have equivalent efficacies to that of bradykinin. When considered together with the actions of these agents on DRG neurons, it is reasonable to assume that the allodynia produced by the chemokines and gp120 coat proteins arises from actions exerted at the peripheral terminals of the small diameter nociceptors. However, this does not exclude an action of these agents at non-neuronal sites in the hindpaw. Agents administered peripherally have the potential to distribute centrally, and recent work by Watkins and colleagues (Milligan et al., 2000) indicates that chemokines can produce allodynia and hyperalgesia via actions involving microglia in the spinal cord. However, the small volume and amounts administered into the hindpaw make it unlikely that sufficient quantities of the chemokines or gp120 coat proteins accessed this site. Thus these data provide the initial evidence for a local site of action.

Interestingly, it has been shown recently (Machelska et al., 1998) that some leukocytes can secrete the opioid peptide $\beta$-endorphin. These leukocytes are attracted to inflammatory sites by the expression of selectin molecules. Thus it seems likely that leukocytes may produce both proinflammatory (chemokine-mediated) and antinociceptive ( $\beta$-endorphin-mediated) effects by acting directly on sensory neurons. Many chemokines that produced positive responses in our experiments are released from resident leukocytes. Further studies are required to address the issue as to which chemokines actually produce these effects in vivo. Several could be involved. Thus although the magnitude of substance $\mathrm{P}$ release produced by 
individual chemokines was less than bradykinin, diverse chemokines released simultaneously at sites of inflammation could stimulate substance $\mathrm{P}$ release additively.

Our observations have several important implications. Stimulation of chemokine receptors on nociceptors can produce pain. Chemokines released from leukocytes in inflammatory infiltrates could be directly responsible for some of the heightened pain sensitivity observed in cases of inflammation. If this is so, then it is likely that chemokine receptor antagonists may constitute a novel class of analgesic for the treatment of inflammatory pain. In addition, the fact that gp120s also can produce direct excitatory effects on nociceptors suggests that the activation of DRG chemokine receptors could be responsible for the chronic pain sensitivity commonly reported in association with HIV-1 infection (Griffin et al., 1998; Bouhassira et al., 1999). An indirect action of gp120s mediated by spinal microglia and astrocytes also may contribute to the pain state (Watkins and Maier, 1999; Milligan et al., 2000). Therefore, appropriate chemokine receptor antagonists may be therapeutic in these cases as well.

\section{REFERENCES}

Asensio VC, Campbell IL (1999) Chemokines in the CNS: plurifunctional mediators in diverse states. Trends Neurosci 22:504-512.

Baggiolini M, Dewald B, Moser B (1994) Interleukin-8 and related chemotactic cytokines-CXC and $\mathrm{CC}$ chemokines. Adv Immunol 55:97-179.

Bleakman D, Thayer SA, Glaum SR, Miller RJ (1990) Bradykinininduced modulation of calcium signals in rat dorsal root ganglion neurons in vitro. Mol Pharmacol 38:785-796.

Bolin LM, Murray R, Lukacs NW, Strieter RM, Kunkel SL, Schall TJ, Bacon KB (1998) Primary sensory neurons migrate in response to the chemokine RANTES. J Neuroimmunol 81:49-57.

Bouhassira D, Attal N, Willer JC, Brasseur L (1999) Painful and painless peripheral sensory neuropathies due to HIV infection: a comparison using quantitative sensory evaluation. Pain 80:265-272.

Brannagan 3rd TH, Nuovo GJ, Hays AP, Latov N (1997) Human immunodeficiency virus infection of dorsal root ganglion neurons detected by polymerase chain reaction in situ hybridization. Ann Neurol 42:368-372.

Brelot A, Heveker N, Pleskoff O, Sol N, Alizon M (1997) Role of the first and third extracellular domains of CXCR-4 in human immunodeficiency virus coreceptor activity. J Virol 71:4744-4751.

Caterina MJ, Schumacher MA, Tominaga M, Rosen TA, Levine JD, Julius D (1997) The capsaicin receptor: a heat-activated ion channel in the pain pathway [see comments]. Nature 389:816-824.

Cesare P, McNaughton P (1996) A novel heat-activated current in nociceptive neurons and its sensitization by bradykinin [see comments]. Proc Natl Acad Sci USA 93:15435-15439.

Chaplan SR, Bach FW, Pogrel JW, Chung JM, Yaksh TL (1994) Quantitative assessment of tactile allodynia in the rat paw. J Neurosci Methods 53:55-63.

Choe W, Albright A, Sulcove J, Jaffer S, Hesselgesser J, Lavi E, Crino P, Kolson DL (2000) Functional expression of the seven-transmembrane HIV-1 co-receptor APJ in neural cells. J Neurovirol 6[Suppl 1]:S61-S69.

Chrousos GP (1998) Stressors, stress, and neuroendocrine integration of the adaptive response. The 1997 Hans Selye Memorial Lecture. Ann NY Acad Sci 851:311-335.

Dittmer D, Kedes DH (1998) Do viral chemokines modulate Kaposi's sarcoma? BioEssays 20:367-370.

Dray A (1997) Kinins and their receptors in hyperalgesia. Can J Physiol Pharmacol 75:704-712.

Eron Jr JJ, Ashby MA, Giordano MF, Chernow M, Reiter WM, Deeks SG, Lavelle JP, Conant MA, Yangco BG, Pate PG, Torres RA, Mitsuyasu RT, Twaddell T (1996) Randomised trial of MNrgp120 HIV-1 vaccine in symptomless HIV-1 infection [see comments]. Lancet 348:1547-1551.

Ferguson SS, Zhang J, Barak LS, Caron MG (1998) Molecular mechanisms of G-protein-coupled receptor desensitization and resensitization. Life Sci 62:1561-1565.

Goehler LE, Gaykema RP, Nguyen KT, Lee JE, Tilders FJ, Maier SF, Watkins LR (1999) Interleukin- $1 \beta$ in immune cells of the abdominal vagus nerve: a link between the immune and nervous systems? J Neurosci 19:2799-2806.

Griffin JW, Crawford TO, McArthur JC (1998) Peripheral neuropathies associated with HIV infection. In: The neurology of AIDS (Gendelman HE, Lipton SA, Epstein L, Swindells S, eds), pp 275-291. New York: Chapman \& Hall.

Gu JG, MacDermott AB (1997) Activation of ATP P2X receptors elicits glutamate release from sensory neuron synapses. Nature 389:749-753. Guo A, Vulchanova L, Wang J, Li X, Elde R (1999) Immunocytochemical localization of the vanilloid receptor 1 (VR1): relationship to neuropeptides, the P2X3 purinoceptor, and IB4 binding sites. Eur J Neurosci 11:946-958.

Hamill OP, Marty A, Neher E, Sakmann B, Sigworth FJ (1981) Improved patch-clamp techniques for high-resolution current recording from cells and cell-free membrane patches. Pfl fgers Arch 391:85-100.

Hesselgesser J, Halks-Miller M, DelVecchio V, Peiper SC, Hoxie J, Kolson DL, Taub D, Horuk R (1997) CD4-independent association between HIV-1 gp120 and CXCR4: functional chemokine receptors are expressed in human neurons. Curr Biol 7:112-121.

Hewitt DJ, McDonald M, Portenoy RK, Rosenfeld B, Passik S, Breitbart W (1997) Pain syndromes and etiologies in ambulatory AIDS patients. Pain 70:117-123.

Horuk R (1999) Chemokine receptors and HIV-1: the fusion of two major research fields. Immunol Today 20:89-94.

Levine JD, Fields HL, Basbaum AI (1993) Peptides and the primary afferent nociceptor. J Neurosci 13:2273-2286.

Limatola C, Giovannelli A, Maggi L, Ragozzino D, Castellani L, Ciotti MT, Vacca F, Mercanti D, Santoni A, Eusebi F (2000) SDF- $1 \alpha-$ mediated modulation of synaptic transmission in rat cerebellum. Eur J Neurosci 12:2497-2504.

Machelska H, Cabot PJ, Mousa SA, Zhang Q, Stein C (1998) Pain control in inflammation governed by selectins [see comments]. Nat Med 4:1425-1428.

Meucci O, Fatatis A, Simen AA, Bushell TJ, Gray PW, Miller RJ (1998) Chemokines regulate hippocampal neuronal signaling and gp120 neurotoxicity. Proc Natl Acad Sci USA 95:14500-14505.

Meucci O, Fatatis A, Simen AA, Miller RJ (2000) Expression of CX3CR1 chemokine receptors on neurons and their role in neuronal survival. Proc Natl Acad Sci USA 97:8075-8080.

Millan MJ (1999) The induction of pain: an integrative review. Prog Neurobiol 57:1-164.

Miller RJ, Meucci O (1999) AIDS and the brain: is there a chemokine connection? Trends Neurosci 22:471-479.

Milligan ED, Mehmert KK, Hinde JL, Harvey LO, Martin D, Tracey KJ, Maier SF, Watkins LR (2000) Thermal hyperalgesia and mechanical allodynia produced by intrathecal administration of the human immunodeficiency virus-1 (HIV-1) envelope glycoprotein, gp120. Brain Res 861:105-116.

Murphy PM, Baggiolini M, Charo IF, Hebert CA, Horuk R, Matsushima K, Miller LH, Oppenheim JJ, Power CA (2000) International Union of Pharmacology. XXII. Nomenclature for chemokine receptors. Pharmacol Rev 52:145-176.

Pleskoff O, Sol N, Labrosse B, Alizon M (1997) Human immunodeficiency virus strains differ in their ability to infect $\mathrm{CD} 4{ }^{+}$cells expressing the rat homolog of CXCR-4 (fusin). J Virol 71:3259-3262.

Simen AA, Miller RJ (1998) Structural features determining differential receptor regulation of neuronal Ca channels. J Neurosci 18:3689-3698.

Thayer SA, Perney TM, Miller RJ (1988) Regulation of calcium homeostasis in sensory neurons by bradykinin. J Neurosci 8:4089-4097.

Vasko MR, Campbell W B, Waite KJ (1994) Prostaglandin E2 enhances bradykinin-stimulated release of neuropeptides from rat sensory neurons in culture. J Neurosci 14:4987-4997.

Vlahakis SR, Algeciras-Schimnich A, Bou G, Heppelmann CJ, VillasisKeever A, Collman RG, Paya CV (2001) Chemokine-receptor activation by env determines the mechanism of death in HIV-infected and uninfected T-lymphocytes. J Clin Invest 107:207-215.

Watkins LR, Maier SF (1999) Implications of immune-to-brain communication for sickness and pain. Proc Natl Acad Sci USA 96:7710-7713.

Weissman D, Rabin RL, Arthos J, Rubbert A, Dybul M, Swofford R, Venkatesan S, Farber JM, Fauci AS (1997) Macrophage-tropic HIV and SIV envelope proteins induce a signal through the CCR5 chemokine receptor. Nature 389:981-985.

Zheng J, Thylin MR, Ghorpade A, Xiong H, Persidsky Y, Cotter R, Niemann D, Che M, Zeng YC, Gelbard HA, Shepard RB, Swartz JM, Gendelman HE (1999) Intracellular CXCR4 signaling, neuronal apoptosis, and neuropathogenic mechanisms of HIV-1-associated dementia. J Neuroimmunol 98:185-200. 